\title{
Blood pressure behavior during mechanical thrombectomy and drugs used for conscious sedation or general anesthesia
}

\author{
Comportamento da pressão arterial durante trombectomia mecânica e drogas utilizadas \\ para sedação consciente ou anestesia geral
}

Ráissa Soraya Souza de OLIVEIRA', Vinícius Boaratti CIARLARIELLO ${ }^{1,2}$, Hanna Nery Ferraz MARTINS², Michelle dos Santos LOBATO'1, Renata Carolina Acri Nunes MIRANDA', Flávia Fernandes Manfredi de FREITAS ${ }^{1}$, Rodrigo Meirelles MASSAUD ${ }^{1}$, Thiago Giansante ABUD'1, Carlos Eduardo BACCIN¹, Gisele Sampaio SILVA',2

\begin{abstract}
Background: The optimal blood pressure (BP) during mechanical thrombectomy for acute ischemic stroke is currently unclear. Objective: To investigate BP behavior during mechanical thrombectomy in patients with acute ischemic stroke and its relationship with drugs used for sedation or general anesthesia. Additionally, we investigated the association between BP oscillation during mechanical thrombectomy and recanalization status, and with functional outcome at discharge. Methods: Consecutive patients treated with mechanical thrombectomy for acute ischemic stroke were evaluated in a tertiary hospital from December/2009 to December/2015. Maximum, minimum, and mean systolic and diastolic BP, and mean arterial pressures were collected during the procedure. Sedative drugs were also reviewed. Results: Fifty-three patients with a mean age of 71.9 years $(60.4 \%$ men) were treated with mechanical thrombectomy. The mean reduction in systolic $\mathrm{BP}$ and mean arterial pressure from hospital admission to mechanical thrombectomy were respectively 42 and $36 \mathrm{mmHg}$. During the procedure, oscillations were $50.4 \mathrm{mmHg}$ for systolic, and $33.2 \mathrm{mmHg}$ for diastolic BP. Patients treated with neuromuscular blocking drugs had more oscillation in systolic BP from hospital admission to procedure (51.1 versus $26.2 \mathrm{mmHg}, P=0.06$ ). The use of cisatracurium (43.9 versus $29.6 \mathrm{mmHg}, P=0.02)$ and succinylcholine ( 44.7 versus $29.3 \mathrm{mmHg}, P=0.01$ ) were associated with a significant drop in $B P$ during the procedure. Conclusions: Significant BP oscillation occurs during mechanical thrombectomy. Drugs used for conscious sedation or general anesthesia, specifically neuromuscular blocking agents, might have an influence upon BP levels.
\end{abstract}

Keywords: Stroke; Hemodynamics; Thrombectomy.

\section{RESUMO}

Antecedentes: Atualmente, a pressão arterial ideal durante a trombectomia mecânica em pacientes com acidente vascular cerebral isquêmico agudo não é clara. Objetivo: Investigar o comportamento da pressão arterial durante a trombectomia mecânica em pacientes com acidente vascular cerebral isquêmico agudo e sua relação com os medicamentos utilizados para sedação ou anestesia geral. Adicionalmente, investigar a associação entre a oscilação da pressão arterial durante a trombectomia mecânica e a capacidade de recanalização, além do status funcional no momento da alta hospitalar. Métodos: Avaliação de pacientes tratados com trombectomia mecânica por acidente vascular cerebral isquêmico agudo em um hospital terciário de dezembro/2009 a dezembro/2015. Valores máximos, mínimos e médios da pressão arterial sistólica, pressão diastólica e pressão arterial média foram coletados durante o procedimento. Drogas sedativas utilizadas também foram revisadas. Resultados: Um total de 53 pacientes com idade média de 71,9 anos (60,4\% homens) foram tratados com trombectomia mecânica. A redução média da pressão arterial sistólica e da pressão arterial média desde a internação até a trombectomia mecânica foi respectivamente de $42 \mathrm{mmHg}$ e $36 \mathrm{mmHg}$. Durante o procedimento, as oscilações da pressão arterial foram de 50,4 mmHg para pressão sistólica e 33,2 $\mathrm{mmHg}$ para pressão diastólica. Os pacientes tratados com bloqueadores neuromusculares apresentaram uma tendência a maior oscilação da pressão arterial sistólica desde a internação até o procedimento ( $51,1 \mathrm{mmHg}$ versus 26,2 $\mathrm{mmHg}, \mathrm{P}=0,06)$. $\mathrm{O}$ uso de cisatracúrio $(43,9 \mathrm{mmHg}$ versus $29,6 \mathrm{mmHg}, \mathrm{P}=0,02)$ e succinilcolina $(44,7 \mathrm{mmHg}$ versus $29,3 \mathrm{mmHg}, \mathrm{P}=0,01)$

${ }^{1}$ Hospital Israelita Albert Einstein, São Paulo SP, Brazil.

${ }^{2}$ Universidade Federal de São Paulo, Disciplina de Neurologia Clínica, São Paulo SP, Brazil.

RSSO (D) https://orcid.org/0000-0002-3147-0203;VBC (D) https://orcid.org/0000-0002-7643-9090; HNFM (DD https://orcid.org/0000-0001-7586-1524; MSL (D) https://orcid.org/0000-0001-9635-0942; RCANM (D) https://orcid.org/0000-0002-5326-9092; FFMF(D) https://orcid.org/0000-0003-4375-7620; RMM (iD https://orcid.org/0000-0001-8206-083X;TGA (iD) https://orcid.org/0000-0001-9918-9963; CEB (iD https://orcid.org/0000-0002-5711-0644;

GSS (iD) https://orcid.org/0000-0002-3247-3123

Correspondence: Gisele Sampaio Silva; Email: giselesampaio@hotmail.com.

Conflict of interest: There is no conflict of interest to declare.

Authors' contributions: RSSO, VBC, MSL, RCANM, FFMF, GSS: conceptualization, methodology and data analysis; RSSO, VBC, HNFM, GSS: writing, review and editing; RMM, TGA, CEB, GSS: supervision. All authors approved the final version of the manuscript and agree to be held accountable for the content therein. Received on May 26, 2020; Received in its final form on August 24, 2020; Accepted on October 12, 2020. 
foram associados a uma queda significativa da pressão arterial durante o procedimento. Conclusões: Durante a trombectomia mecânica ocorre oscilação significativa da pressão arterial. Os medicamentos usados para sedação consciente ou anestesia geral, especificamente bloqueadores neuromusculares, podem ter influência nos níveis de pressão arterial.

Palavras-chave: Acidente Vascular Cerebral; Hemodinâmica; Trombectomia.

\section{INTRODUCTION}

Mechanical thrombectomy (MT) has become the standard therapy for patients with stroke caused by large vessel occlusions (LVO) up to 24 hours from time last-knownwell (LKW) $)^{1-4}$. Among several factors associated with higher recanalization rates, preservation of collateral flow plays an important role in improving functional outcomes in patients treated with mechanical thrombectomy. Indeed, collateral blood flow could be affected by management of blood pressure $(\mathrm{BP})^{5,6}$, and there is a specific concern about BP drops due to anesthesia during the procedure ${ }^{7-13}$. The optimal BP during mechanical thrombectomy for acute ischemic stroke is currently unclear, and most of the institutions do not have a standardized protocol for BP management ${ }^{14}$.

The role of conscious sedation versus general anesthesia (GA) in functional outcome is still a matter of debate. Although GA allows a more controlled procedure, BP drops during the administration of anesthetics could lead to failure of the collateral circulation ${ }^{7-13}$. Similarly, small decreases in BP during conscious sedation also seem to affect clinical outcome after thrombectomy ${ }^{15}$. On the other hand, higher BP levels following mechanical thrombectomy were independently associated with an increased likelihood of mortality and functional dependence in patients with $\mathrm{LVO}^{16}$.

The objective of this study was to evaluate BP behavior during mechanical thrombectomy in patients with acute ischemic stroke and its relationship with drugs used for sedation or GA during the procedure.

\section{METHODS}

\section{Patients and data collection}

We evaluated consecutive patients treated with mechanical thrombectomy for acute ischemic stroke in a tertiary hospital certified by the Joint Commission International as a Primary Stroke Centre in São Paulo, Brazil, from December 2009 to December 2015. Large vessel occlusion was diagnosed on pretreatment CT angiography (CTA) using standard criteria. Data collected included demographics, stroke risk factors, National Institutes of Health Stroke Scale (NIHSS) score at admission, neuroimaging characteristics (admission ASPECTS), and modified Rankin Scale score at discharge. The NIHSS scores were documented by certified neurologists.
Risk factors were considered if noted on the patient's chart or if medications for known risk factors were used before hospital admission or at discharge.

BP levels were documented at least every 15 minutes during mechanical thrombectomy. We collected maximum, minimum, and mean values of systolic and diastolic BP, and mean arterial pressures during the procedure, the time from symptom onset to groin puncture, and post-intervention recanalization assessment on the final digital subtraction angiography.

The devices used included the Solitaire stent retriever or the Penumbra aspiration system. The choice of procedural anesthesia was decided by a consensus between the neurointerventional radiologist and the neurologist. Drugs used for either conscious sedation or GA were reviewed. Recanalization status was determined with the modified Treatment in Cerebral Infarction (mTICI) score, categorized as 0, I, IIa, IIb, and III. Complete reperfusion at the end of endovascular procedure was defined by TICI scores of IIb or III. This study was approved by the Local Ethics Committee of the Hospital Israelita Albert Einstein and the following procedures were in accordance with institutional guidelines.

\section{Statistical analysis}

Continuous variables were presented as mean and standard deviation $( \pm \mathrm{SD})$ or median and interquartile range $( \pm$ IQR). Data were analyzed for normal distribution. Statistical comparisons for categorical variables between two groups were performed using the $\chi^{2}$ test. Continuous variables were compared by unpaired (when normal data between two groups were being compared) and paired t test (when normal data from the same patient in two different moments were being compared) or the Mann-Whitney U test (when nonnormal data from different groups were being compared).

Analyses were performed with a two-sided alpha level of 0.05. The Statistical Package for Social Science version 20.0 for Windows (SPSS Inc., Chicago, IL) was used for statistical analyses.

\section{RESULTS}

We evaluated 53 patients with a mean age of 71.9 years (60.4\% men) who were treated with mechanical thrombectomy. The median NIHSS and ASPECTS scores were 17 
points [IQR 12-22] and 8 points [IQR 6.5-10], respectively. Baseline characteristics, including BP at admission and successful recanalization rate, are presented in Table 1. Sites of occlusion were in the anterior circulation (M1 and M2) in 50 patients $(94.3 \%)$ and in the basilar artery in three patients (5.7\%). Intravenous thrombolysis prior to mechanical thrombectomy was administered in eight patients (15.1\%).

Stent retrievers without distal aspiration (most common technique) were used in 34 patients (64.1\%). A Direct Aspiration First Pass Technique (ADAPT) was used in 12 cases $(22.6 \%)$ while a combination of distal aspiration and stent retriever was used in seven patients (13.2\%). The median time from door to arterial puncture was 120 minutes [IQR 97.2-166.7]. Complete reperfusion was achieved in 34 patients $(64.1 \%)$. The median NIHSS at hospital discharge was 5 [2,11] (median NIHSS change from hospital admission $-8[-4,-11], \mathrm{P}<0.01)$. GA was used in 47 patients $(88.7 \%)$ and six $(11.3 \%)$ patients were managed with conscious sedation. The frequency of the drugs used during the procedure is described in Table 2.

BP behavior during mechanical thrombectomy is depicted in Table 3 and Figure 1. The mean reduction in systolic BP and mean arterial pressure from hospital admission to mechanical thrombectomy (minimal systolic BP during procedure) were $42.0 \pm 36.0$ and $36.0 \pm 26.1 \mathrm{mmHg}$, respectively. During mechanical thrombectomy, oscillations in BP (maximal minus minimal BP, during the procedure) were 50.4 $\mathrm{mmHg}( \pm 26.8)$ for systolic BP, and $33.2 \mathrm{mmHg}( \pm 19.3)$ for diastolic BP. Patients treated under GA had a trend to have more oscillation in $\mathrm{BP}$ during the procedure when compared to patients treated under conscious sedation $(34.8 \pm 19.2 \mathrm{mmHg}$ in GA versus $21.1 \pm 16.9 \mathrm{mmHg}$ in conscious sedation, $\mathrm{P}=0.11$ ).

There were no differences is BP variation when using different drugs for sedation (propofol, midazolam, etomidate, fentanyl and remifentanil). Patients treated with neuromuscular blocking drugs had a trend towards more oscillation in systolic BP from hospital admission to mechanical thrombectomy $(51.1 \pm 38.8$ versus $26.2 \pm 35.3 \mathrm{mmHg}, \mathrm{P}=0.06)$. Considering the use of specific neuromuscular blocking agents, cisatracurium $(43.9 \pm 17.5$ versus $29.6 \pm 18.8 \mathrm{mmHg}$, $\mathrm{P}=0.02)$ and succinylcholine $(44.7 \pm 18.6$ versus $29.3 \pm 18.2$ $\mathrm{mmHg}, \mathrm{P}=0.01$ ) were associated with a significant drop in $\mathrm{BP}$ during the procedure. BP oscillation during mechanical thrombectomy was not associated with recanalization status nor with functional outcome at discharge.

Table 1. Baseline characteristics of the patients.

\begin{tabular}{lcc}
\hline & $\mathrm{N}=53$ & ( SD) or [IQR] \\
\hline Age, $\mathrm{y}$ (mean) & 71.9 & \pm 15.7 \\
Male sex & $32(60.4 \%)$ & - \\
\hline Hypertension & $30(56.6 \%)$ & - \\
\hline Diabetes mellitus & $13(24.5 \%)$ & - \\
\hline Dyslipidemia & $11(20.7 \%)$ & - \\
Atrial fibrillation & $16(30.1 \%)$ & {$[12-22]$} \\
Baseline NIHSS score, points (median) & 17 & - \\
IV thrombolysis & $8(15.1 \%)$ & \pm 30 \\
Admission systolic BP, mmHg (mean) & 144 & \pm 19 \\
Admission diastolic BP, mmHg (mean) & 82 & \pm 20 \\
Admission mean BP, mmHg (mean) & 102 & {$[6.5-10]$} \\
\hline ASPECTS score (median) & 8 & - \\
\hline Successful recanalization & $34(64.1 \%)$ & - \\
\hline
\end{tabular}

ASPECTS: Alberta Stroke Program Early Computed Tomography; BP: blood pressure; IQR: interquartile range; IV: intravenous; mmHg: millimeters of Mercury; NIHSS: National Institutes of Health Stroke Scale; SD: standard deviation.

Table 2. Drug used for general anesthesia or conscious sedation.

\begin{tabular}{lc}
\hline Drug & Patients \\
\hline Propofol & $11(20.7 \%)$ \\
Midazolam & $26(49 \%)$ \\
Fentanyl or Remifentanyl & $23(43.3 \%)$ \\
Etomidate & $16(30.1 \%)$ \\
Rocuronium & $21(39.6 \%)$ \\
Cisatracurium & $13(24.5 \%)$ \\
Succinylcholine & $14(26.4 \%)$ \\
\hline
\end{tabular}


Table 3. Blood pressure behavior during mechanical thrombectomy according to the drug used.

\begin{tabular}{|c|c|c|c|c|}
\hline Drug & $\begin{array}{l}\mathrm{SAP} \max , \mathrm{mmHg} \\
\quad(\text { mean } \pm \mathrm{SD})\end{array}$ & $\begin{array}{l}\text { MAP max, mmHg } \\
\quad(\text { mean } \pm \text { SD })\end{array}$ & $\begin{array}{l}\text { SAP min, } \mathrm{mmHg} \\
\quad(\text { mean } \pm \mathrm{SD})\end{array}$ & $\begin{array}{l}\text { MAP min, } \mathrm{mmHg} \\
\quad(\text { mean } \pm \mathrm{SD})\end{array}$ \\
\hline Propofol (N:22) & $154.4 \pm 20.9$ & $101.7 \pm 17.7$ & $107.2 \pm 11.8$ & $69.9 \pm 13.7$ \\
\hline Midazolam (N:27) & $156.8 \pm 21.7$ & $100.5 \pm 16.1$ & $102 \pm 20.8$ & $65.6 \pm 15.7$ \\
\hline Fentanyl or Remifentanil (N: 45) & $153.6 \pm 21.4$ & $99.6 \pm 17.7$ & $103.0 \pm 16.0$ & $66.5 \pm 13.8$ \\
\hline Etomidate (N:17) & $153.5 \pm 17.6$ & $102.4 \pm 16.1$ & $98.5 \pm 17.7$ & $64.7 \pm 15.5$ \\
\hline Rocuronium (N:21) & $151 \pm 23.0$ & $98.3 \pm 12.9$ & $100.3 \pm 16.3$ & $70.5 \pm 13.8$ \\
\hline Cisatracurium (N:14) & $155.2 \pm 21.6$ & $104.7 \pm 16.6$ & $95.5 \pm 19.2$ & $61.9 \pm 14.3$ \\
\hline Succinylcholine (N:15) & $161.6 \pm 21.2$ & $111.8 \pm 17.8$ & $102.0 \pm 15.8$ & $68.2 \pm 12.7$ \\
\hline
\end{tabular}

MAP: mean arterial blood pressure; SAP: systolic arterial blood pressure; mmHg: millimeters of Mercury; SD: standard deviation; max: maximum; min: minimum.

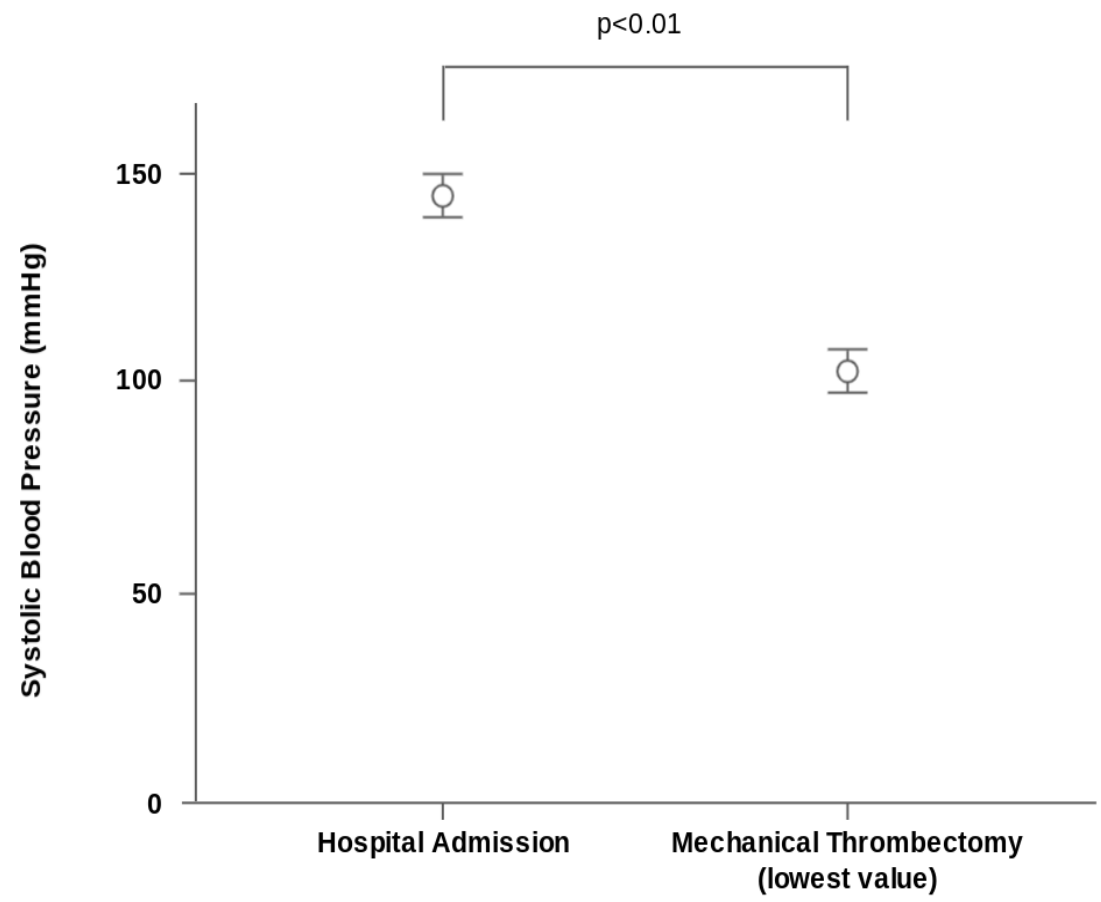

Figure 1. Systolic blood pressure variation during mechanical thrombectomy.

\section{DISCUSSION}

In this study, baseline characteristics of patients treated with mechanical thrombectomy for acute ischemic stroke matched similar findings previously described in the setting of this tertiary hospital service and nationwide stroke popula$\operatorname{tion}^{17}$. There was only a consideration for higher NIHSS scores in this study compared to a previous publication (17 versus 3 ) and for frequency of atrial fibrillation (30 versus $15.5 \%)^{17}$. Indeed, this would be expected in a large vessel occlusion population.

There is a special concern for potential features that could worsen tissue perfusion during mechanical thrombectomy. Decreases in cerebral perfusion pressure could be directly related to drops in mean arterial $\mathrm{BP}^{18-21}$. This study suggests that significant BP oscillation occurs during mechanical thrombectomy. The reduction of the mean systolic BP during the procedure was more than $40 \mathrm{mmHg}$, which might worsen tissue perfusion, especially in patients in whom recanalization was not achieved ${ }^{18-21}$. On the other hand, high maximum systolic BP following MT was previously addressed as an independent risk factor for 3-month mortality and functional dependence in LVO patients ${ }^{16}$. Thereby, this could mean that there is a U-shaped association of BP and functional stroke outcomes ${ }^{22}$.

There were few patients who were treated with mechanical thrombectomy under conscious sedation (six patients), and comparison with general anesthesia was limited. However, significant changes in BP were seen in both groups, raising the question whether conscious sedation is protective or not ${ }^{7-9}$. Furthermore, drugs used for conscious sedation were similar to those used in GA, except for the doses applied.

Another important difference between GA and conscious sedation is the use of neuromuscular blockers in the 
former ${ }^{23,24}$. Cisatracurium is an intermediate long-acting nondepolarizing neuromuscular blocking agent while succinylcholine is a depolarizing neuromuscular-blocking drug ${ }^{25}$. The hemodynamic effects of neuromuscular blockers are well described in the literature, and such effects may be attributed to histamine release and/or acetylcholine-like effects ${ }^{26,27}$. Interestingly we found a significant drop in BP in patients treated with cisatracurium and succinylcholine.

This study had some limitations. Firstly, this was an observational single-center study with relatively small sample size and non-matched control group, which limited analysis to multivariable adjustments. Furthermore, past medical history might have influenced the choice of the drugs used for GA or sedation, which could be a bias in our analysis. Data about the use of vasopressors during the procedure, the doses used of each drug, the doses of specific neuromuscular agents per kilogram used for each patient, as well as the data about blood pressure oscillation in patients that used a combination of drugs were not collected. Finally, there is no data on the influence of BP drop upon long-term functional outcome. Nonetheless, this study is the first to our knowledge to raise the question of the role of specific drugs used for GA or sedation upon BP level in patients treated with mechanical thrombectomy. Further studies are required to better understand the role of sedatives, anesthetics, and neuromuscular blocking agents on functional outcome of patients submitted to mechanical thrombectomy in a setting of acute ischemic stroke.

\section{REFERENCES}

1. Powers WJ, Rabinstein AA, Ackerson T, Adeoye OM, Bambakidis NC, Becker K, et al. 2018 Guidelines for the early management of patients with acute ischemic stroke: a guideline for healthcare professionals from the American Heart Association/American Stroke Association. Stroke. 2018 Mar;49(3):e46-110. https://doi.org/10.1161/ STR.0000000000000158

2. Goyal M, Menon BK, van Zwam WH, Dippel DWJ, Mitchell PJ, Demchuk AM, et al. Endovascular thrombectomy after large-vessel ischaemic stroke: a meta-analysis of individual patient data from five randomised trials. Lancet. 2016 Apr 23;387(10029):1723-31. https:// doi.org/10.1016/S0140-6736(16)00163-X

3. Nogueira RG, Jadhav AP, Haussen DC, Bonafre A, Budzik RF, Bhuva P, et al. Thrombectomy 6 to 24 hours after stroke with a mismatch between deficit and infarct. N Engl J Med. 2018 Jan 4;378(1):11-21. https://doi.org/10.1056/NEJMoa1706442

4. Albers GW, Marks MP, Kemp S, Christensen S, Tsai JP, OrtegaGutierrez S, et al. Thrombectomy for stroke at 6 to 16 hours with selection by perfusion imaging. N Engl J Med. 2018 Feb;378(8):70818. https://doi.org/10.1056/NEJMoa1713973

5. Nogueira RG, Liebeskind DS, Sung G, Duckwiler G, Smith WS, Multi MERCI Writing Committee. Predictors of good clinical outcomes, mortality, and successful revascularization in patients with acute ischemic stroke undergoing thrombectomy: pooled analysis of the mechanical embolus removal in cerebral ischemia (merci) and multi merci trials. Stroke. 2009 Dec;40(12):3777-83. https://doi. org/10.1161/STROKEAHA.109.561431

6. Lin MP, Tsivgoulis G, Alexandrov AV, Chang JJ. Factors affecting clinical outcome in large-vessel occlusive ischemic strokes. Int J Stroke. 2015 Jun;10(4):479-84. https://doi.org/10.1111/ijs.12406

7. Schönenberger S, Möhlenbruch M, PfaffJ, Mundiyanapurath S, Kieser M, Bendszus M, et al. Sedation vs. Intubation for endovascular stroke treatment (SIESTA) - a randomized monocentric trial. Int J Stroke. 2015 Aug;10(6):969-78. https://doi.org/10.1111/ijs.12488

8. Brinjikji W, Pasternak J, Murad MH, Cloft HJ, Welch TL, Kallmes DF, et al. Anesthesia-related outcomes for endovascular stroke revascularization: a systematic review and meta-analysis. Stroke. 2017 Oct;48(10):2784-91. https://doi.org/10.1161/ STROKEAHA.117.017786

9. Wang A, Stellfox M, Moy F, Abramowicz AE, Lehrer R, Epstein R, et al. General anesthesia during endovascular stroke therapy does not negatively impact outcome. World Neurosurg. 2017 Mar;99:638-43. https://doi.org/10.1016/j.wneu.2016.12.064

10. Bekelis K, Missios S, MacKenzie TA, Tjoumakaris S, Jabbour P. Anesthesia technique and outcomes of mechanical thrombectomy in patients with acute ischemic stroke. Stroke. 2017 Feb;48(2):361-66. https://doi.org/10.1161/STROKEAHA.116.015343

11. Treurniet KM, Berkhemer OA, Immink RV, Lingsma HF, Ward-van der Stam VMC, Hollmann MW, et al. A decrease in blood pressure is associated with unfavorable outcome in patients undergoing thrombectomy under general anesthesia. J Neurointerv Surg. 2018 Feb;10(2):107-11. https://doi.org/10.1136/neurintsurg-2017-012988

12. Schönenberger S, Uhlmann L, Ungerer M, Pfaff J, Nagel S, Klose C, et al. Association of blood pressure with short- and long-term functional outcome after stroke thrombectomy: post hoc analysis of the siesta trial. Stroke. 2018 Jun;49(6):1451-6. https://doi. org/10.1161/STROKEAHA.117.019709

13. Schönenberger S, Uhlmann L, Hacke W, Schieber S, Mundiyanapurath S, Purrucker JC, et al. Effect of conscious sedation vs general anesthesia on early neurological improvement among patients with ischemic stroke undergoing endovascular thrombectomy: a randomized clinical trial. JAMA. 2016 Nov 15:316(19):1986-96. https://doi.org/10.1001/jama.2016.16623

14. Mistry EA, Mayer SA, Khatri P. Blood pressure management after mechanical thrombectomy for acute ischemic stroke: a survey of the strokenet sites. J Stroke Cerebrovasc Dis. 2018 Sep;27(9):2474-8. https://doi.org/10.1016/j.jstrokecerebrovasdis.2018.05.003

15. Whalin MK, Halenda KM, Haussen DC, Rebello LC, Frankel MR, Gershon RY, et al. Even small decreases in blood pressure during conscious sedation affect clinical outcome after stroke thrombectomy: an analysis of hemodynamic thresholds. AJNR Am J Neuroradiol. 2017 Feb;38(2):294-8. https://doi.org/10.3174/ajnr. A4992

16. Goyal N, Tsivgoulis G, Pandhi A, Chang JJ, Dillard K, Ishfaq MF, et al. Blood pressure levels post mechanical thrombectomy and outcomes in large vessel occlusion strokes. Neurology. 2017 Aug 8;89(6):540-7. https://doi.org/10.1212/WNL.0000000000004184

17. Schneider LSV, Ciarlariello VB, Miranda RCAN, Vaccari AH, Massaud RM, Silva GS. Get with the Guidelines®-Stroke performance indicators in patients with transient ischemic attack. Arq Neuropsiquiatr. 2018 Sep;76(9):599-602. https://doi. org/10.1590/0004-282×20180088

18. Oliveira-Filho J, Silva SCS, Trabuco CC, Pedreira BB, Sousa EU, Bacellar A. Detrimental effect of blood pressure reduction in the first 24 hours of acute stroke onset. Neurology. 2003 Oct 28;61(8):104751. https://doi.org/10.1212/01.WNL.0000092498.75010.57

19. Liebeskind DS. Solving the mystery of blood pressure in acute stroke. South Med J. 2006 Nov;99(11):1207-8. https://doi.org/10.1097/01. smj.0000248815.21233.4f 
20. Lima FO, Furie KL, Silva GS, Lev MH, Camargo ECS, Singhal AB, et al. The pattern of leptomeningeal collaterals on CT angiography is a strong predictor of long-term functional outcome in stroke patients with large vessel intracranial occlusion. Stroke. 2010 Oct;41(10):2316-22. https://doi.org/10.1161/STROKEAHA.110.592303

21. Seyman E, Shaim H, Shenhar-Tsarfaty S, Jonash-Kimchi T, Bornstein NM, Hallevi H. The collateral circulation determines cortical infarct volume in anterior circulation ischemic stroke. BMC Neurol. 2016 Oct;16(1):206. https://doi.org/10.1186/s12883-016-0722-0

22. Vitt JR, Trillanes M, Hemphill JC. Management of blood pressure during and after recanalization therapy for acute ischemic stroke. Front Neurol. 2019 Feb 21;10:138. https://doi.org/10.3389/ fneur.2019.00138

23. Higgs A, McGrath BA, Goddard C, Rangasami J, Suntharalingam G, Gale R, et al. Guidelines for the management of tracheal intubation in critically ill adults. Br J Anaesth. 2018 Feb;120(2):323-52. https://doi. org/10.1016/j.bja.2017.10.021
24. Mosier JM, Sakles JC, Stolz U, Hypes CD, Chopra H, Malo J, et al. Neuromuscular blockade improves first-attempt success for intubation in the intensive care unit a propensity matched analysis. Ann Am Thorac Soc. 2015 May;12(5):734-41. https://doi.org/10.1513/ AnnalsATS.201411-51700

25. Donati F. Neuromuscular blocking drugs for the new millennium: current practice, future trends--comparative pharmacology of neuromuscular blocking drugs. Anesth Analg. 2000 May;90(5):S2-6. https://doi.org/10.1097/00000539-200005001-00002

26. Correa CMN, Sudo GZ, Sudo RT. Hemodynamic effects of atracurium and cisatracurium and the use of diphenhydramine and cimetidine. Rev Bras Anestesiol. 2010 Jan-Feb;60(1):52-63. https://doi. org/10.1016/S0034-7094(10)70006-4

27. Ghorbanlo M, Mohaghegh MR, Yazdanian F, Mesbah M, Totonchi Z. A comparison between the hemodynamic effects of cisatracurium and atracurium in patient with low function of left ventricle who are candidate for open heart surgery. Medical Arch. $2016 \mathrm{Jul}$ 27;70(4):265-8. https://doi.org/10.5455/medarh.2016.70.265-268 